\title{
Prevalence study of sun protection behaviors / practices in several representative population samples in Indonesia
}

\author{
Yoshiyuki Ohno ${ }^{1}$, Joedo Prihartono ${ }^{2}$, Masamitsu Ichihashi ${ }^{3}$, Setyawati Budiningsih ${ }^{2}$, Mochtar Hamzah $^{4}$, \\ Santoso Cornain ${ }^{5}$, Masato Ueda ${ }^{3}$, Mpu Kanoko ${ }^{5}$, Evert Poetiray ${ }^{6}$, Nobuo Munakata ${ }^{7}$, Herman Cipto ${ }^{4}$, \\ Achmad Tjarta ${ }^{5}$, Arman Mukhtar
}

\begin{abstract}
Abstrak
Kanker kulit non-melanoma (KKNM) yang agak sering ditemukan dan tersebar di berbagai negara di dunia, diperkirakan paling mungkin dicegah dengan perubahan perilaku yang sederhana. Ini menyebabkan para penulis untuk mengusulkan prevalensi dari perilakwpraktek berlindung dari sinar matahari diantara beberapa contoh populasi yang representatif di Indonesia. Penelitian prevalensi adalah penting untuk memperoleh data yang diperlukan untuk menghitung proporsi yang dapat dicegah, yaitu "population attributable risk percentage" (PARP) dari KKNM di Indonesia. PARP dapat diperoleh dengan memasukkan proporsi populasi yang melakukan perilaku perlindungan bersama dengan Rasio Odds untuk KKNM, yang akan diperoleh pada penelitian kasus-kontrol, ke dalam rumus perhitungan, seperti diuraikan secara terperinci dalam bagian kedua dari makalah ini. Sebelum kami dapat memperoleh proporsi yang dapat dicegah yang khas untuk negara dan khas untuk kelompok etnik dari KKNM oleh tiap perilakwpraktek perlindungan terhadap sinar matahari di Indonesia, kami mengajukan 10 pedoman sederhana untuk membantu mengurangi risiko terjadinya kanker kulit, yang disarankan di Amerika Serikat, karena dipandang berguna untuk Indonesia sebagai pedoman sementara untuk pencegahan KKNM.
\end{abstract}

\begin{abstract}
Non-melanoma skin cancer (NMSC), which is rather common and worldwide, is considered to be mostly preventable by simple behavioral change. This initiated the authors to propose a prevalence, study of sun protection behaviors/ practices among several representatives population samples in Indonesia. This prevalence study is essential for providing the prerequisite data to calculate the preventable proportion, i.e. population attributable risk percentage (PARP), of NMSC in Indonesia. The PARP can be obtained by concomitantly inserting the proportion of those practicing each sun protection behavior and its odds ratios for NMSC, which are to be clarified by our ongoing case-control study, into the calculation formula, as described in detail in the second section of this communication. Before we can obtain the country and ethnic group-specific preventable proportion of NMSC by each sun protection behavior/practice in Indonesia, we introduced 10 simples tips to help cut the risk of developing skin cancer, which were recommended in the United States, since they are also considered to be, in part, useful for Indonesians as tentative guidelines for NMSC prevention.
\end{abstract}

Keywords: non-melanoma skin cancer, prevalence, sun-protection behavior, preventable proportion, Indonesia

1 Department of Preventive Medicine, Nagoya University School of Medicine, Nagoya 466-8550, Japan

2 Department of Community Medicine, Faculty of Medicine, University of Indonesia, Jakarta 10320, Indonesia

${ }^{3}$ Department of Dermatology, Kobe University School of Medicine, Kobe 650-0017, Japan

${ }^{4}$ Department of Dermatology, Faculty of Medicine, University of Indonesia, Jakarta 10430, Indonesia

5 Department of Anatomic Pathology, Faculty of Medicine, University of Indonesia, Jakarta 10430, Indonesia

${ }^{6}$ Department of Surgery, Faculty of Medicine, University of Indonesia, Jakarta 10430, Indonesia

${ }^{7}$ Radiobiology Division, National Cancer Center Research Institute, Tokyo 104-0045, Japan
Non-melanoma skin cancer (NMSC) is the most common type of cancer in white population, and its incidence has increased worldwide over the last few decades. $^{1-4}$ This increasing trend might be in part ascribed to such recently changed environmental and socio-cultural conditions as depletion of the atmospheric ozone layer, increasing aged population (in developed countries in particular), increasing outdoor recreational activities at shadeless sites, increasing concern about NMSC among the public at large which resulted in much earlier hospital visits, and earlier diagnosis/ recognition by medical professionals who have become more aware of NMSC. ${ }^{4}$ 
According to numerous investigations mostly on Caucasians, as reviewed, ${ }^{5-7}$ the primary risk factors for development of NMSC are excessive ultraviolet radiation and personal characteristics associated with increased skin sensitivity to ultraviolet radiation such as light skin color, easy sunburning, and little or no ability to tan. Relevant epidemiological evidence is summarized $^{7}$ as follows: NMSC occurs (1) more frequently in residents of areas with high ambient solar irradiance, (2) more frequently in sun-sensitive people, (3) mainly on sun-exposed body sites, (4) more frequently in people with high sun exposure, and (5) more frequently in people with benign sunrelated skin conditions, and NMSC is (6) reduced by protection of the skin against the sun. In our JapanIndonesia joint research project on skin cancer, an importance of sun exposure in developing NMSC was also suggested by the preliminary analysis of the data obtained from ongoing case-control study on skin cancer in Jakarta.

Based on these scientific evidence, the most effective counter-measure against NMSC is considered to be sun protection behaviors/practices such as avoiding sun exposure especially during midday hours, wearing protective clothing and hat and wearing sunscreen lotion with a sun protection factor (SPF) of 15 or higher. ${ }^{8}$

It is also important to note that $80 \%$ of a person's lifetime sun exposure is estimated to occur before the age of $21^{9}$ and that use of a sunscreen with a SPF of 15 or higher during childhood and adolescence may reduce the lifetime risk of both basal and squamous cell carcinomas of the skin by as much as $78 \%$. $^{10}$

In order to develop major countermeasures against NMSC in this country, we need to know the prevalence of actual sun protection behaviors/practices by a deliberate survey in several representative population samples in Indonesia and odds ratio as well by each sun protection behavior, which are basic information for calculating population attributable risk percentage (PARP), because PARP will tell us a preventable proportion of NMSC by each sun protection behavior/practice. Odds ratio by each sun protection behavior will be obtained from our ongoing case-control study in Jakarta, which will be described in detail somewhere in this monograph.

In this communication, therefore, some surveys scheme for a prevalence study on sun protection behaviors/practices will be discussed, including sampling method, organizational framework of the survey and items to be surveyed, along with brief explanation of PARP.

\section{Definition of population attributable risk percent and attributable risk number}

PARP is a genuine indicator of preventable proportion of a given disease in a total population by a given factor, i.e. a proportion (expressed in percentage) of a given disease of outcome in a total population that can be removed if the exposure were avoided completely, under the two assumptions: (1) those with a given factor (ex smokers); and (2) other etiological factors are equally distributed among those exposed and those not-exposed.

PARP is a very useful index in planning and assessing any disease control programs, since it enables health administrators to estimate the extend to which a particular disease is due to a specific factor and to predict the effectiveness of a control program which intend to reduce a specific disease by eliminating exposure to a specified factor.

Conceptual figures and calculation formulae $e^{11}$ are illustrated in Figure 1, when relative risk/odds ratio is larger than unity and in Figure 2, when less than unity. Exemplified calculations are shown in Table 1. In example 1, relative risk of cigarette smoking for lung cancer in males was arbitrarily set to be 4.13 with a proportion (70\%) of current smokers in a total male population and then, PARP was calculated as $68.7 \%$ by inserting 4.13 and 0.70 into the formula in Figure 1 . This $68.7 \%$ implies that this percentage of total lung cancer is due to cigarette smoking; in another words, if all male smokers became nonsmokers, $68.7 \%$ of total lung cancer could be avoided/prevented. In example 2 , relative risk of daily intake of green-yellow vegetables for lung cancer was set to be 0.8 (protective) and daily eaters of greenyellow vegetables were accounted for $40 \%$ in a total population and then, PARP was computed as $8.0 \%$ by inserting 0.8 and 0.40 into the formula in Figure 2. This $8.0 \%$ means that $0.8 \%$ of total lung cancer could be avoided/prevented.

PARP, thus, indicates the proportion (in percentage) of contribution of a certain factor for developing a given diseases or outcome, i.e. preventable proportion by a certain factor. It does not, however, indicate how many people were attributable to a given factor among these with a given disease. This number is 
usually called in epidemiology textbook as attributable risk number (ARN). ${ }^{\text {1 }}$ ARN can be obtained by multiplying PARP by a total number of people with a given disease. It is, therefore, clear that even if PARP is large, ARN will not be large if a given disease is common. PARP and ARN are both important indicators in planning and assessing any disease control programs, exactly under the prerequisite condition that a given disease and a given factor are causally related.

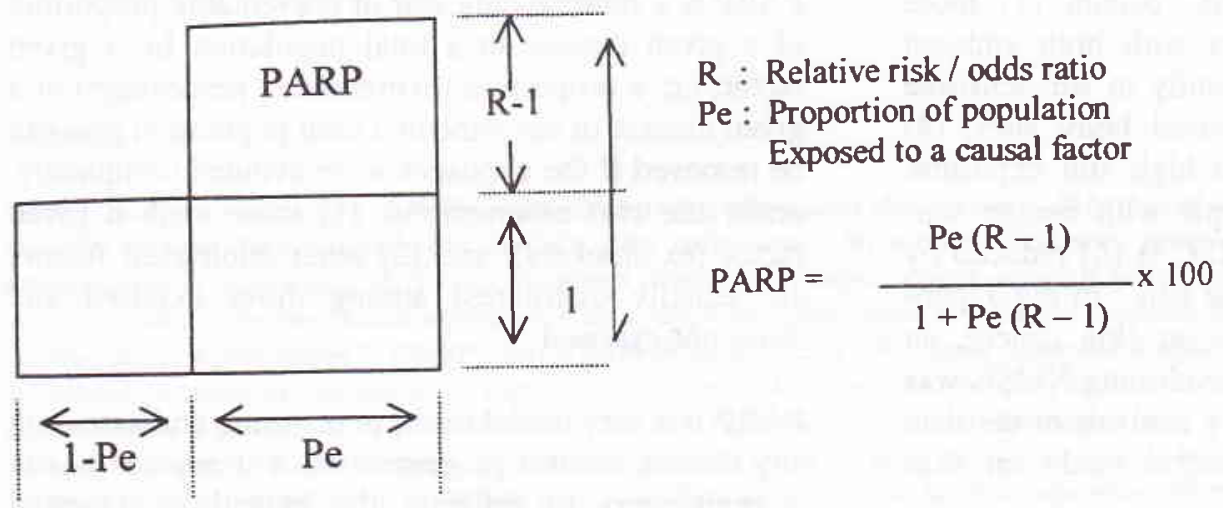

Figure 1. Calculation of population attributable risk percent (PARP) when relative risk/odds ratio is larger than unity

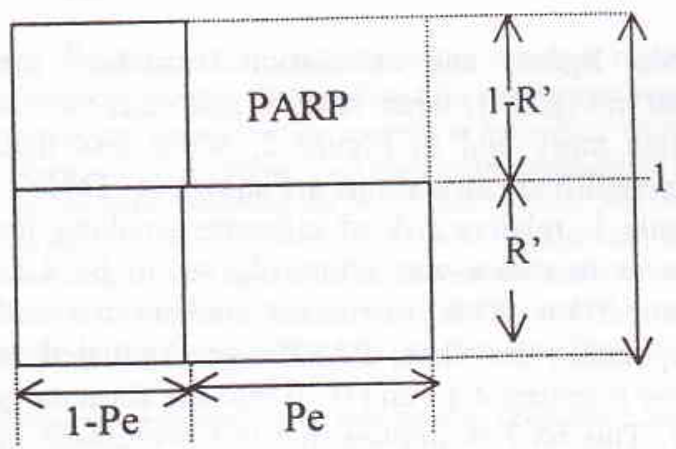

R' : Relative Risk/Odds ratio

Pe : Proportion of population

exposed to a causal factor

$\operatorname{PARP}=\operatorname{Pe}\left(1-R^{\prime}\right) \times 100$

Figure 2. Calculation of population auributable risk percent (PARP) when relative risk/odds ratio is smaller than unity

Table 1. Exemplified calculation of population attributable risk percent (PARP)

Example 1 (when relative risk / odds ratio $\geq 1.00$ )

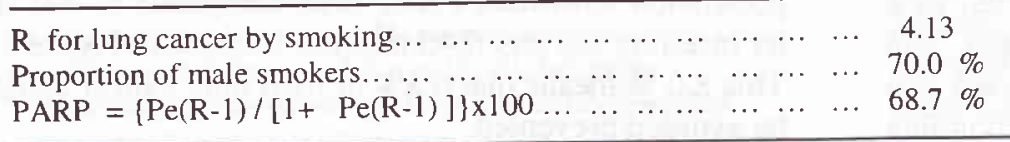

Example 2 (when relative risk / odds ratio $<1.00$ )

$\mathrm{R}$ for lung cancer by daily intake of green-yellow vegetables $\ldots \quad \ldots \quad 0.80$

Proportion of daily eaters of green-yellow vegetables $\ldots \ldots \ldots . \quad \ldots \quad \ldots \quad 40.0 \%$

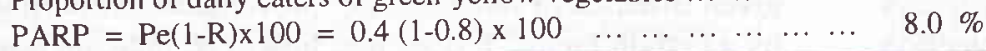


For much clearer understanding Table 2 is presented, that shows a PARP value for selected values of relative risk/odds ratio and proportion of people with a factor. A PARP value increases at a fixed relative risk/odds ratio, when a proportion of those with a factor increases and at a fixed proportion of those with a factor, when relative risk/odds ratio increases.

Table 2. Population attributable risk percent (PARP) for selected values of relative risk/odds ratio and proportion of population with the factor

\begin{tabular}{cccccc}
\hline \multirow{2}{*}{$\begin{array}{c}\text { Pe proportion of people } \\
\text { with the factor }\end{array}$} & \multicolumn{5}{c}{$\mathrm{R}=$ relative risk/odds ratio } \\
\cline { 2 - 6 } & 0.5 & 2 & 4 & 10 & 12 \\
\hline $10 \%$ & $5 \%$ & $9 \%$ & $23 \%$ & $47 \%$ & $52 \%$ \\
30 & 15 & 23 & 47 & 73 & 77 \\
50 & 25 & 33 & 60 & 82 & 84 \\
70 & 35 & 41 & 67 & 86 & 89 \\
90 & 45 & 47 & 73 & 89 & 91 \\
95 & 47 & 49 & 74 & 90 & 92 \\
\hline
\end{tabular}

When $\mathrm{R} \geq 1.00, \mathrm{PARP}=\{\mathrm{Pe}(\mathrm{R}-1) /[1+\mathrm{Pe}(\mathrm{R}-1)]\} \times 100$ When $R<1.00, P A R P=\operatorname{Pe}(1-R) \times 100$

\section{Prevalence study on sun protection behaviors/ practices in Indonesia}

For calculating preventable proportion of skin cancer in Indonesia, we need to know relative risks/odds ratios by each sun protection behavior/practice and proportions of those practicing each sun protection from area to area in Indonesia. The former information will be readily available from our ongoing case-control study on skin cancer. To our best knowledge, the latter information are not readily available at moment from any sources in Indonesia. This essentially means for us to have to undertake our own prevalence study in representative population samples in Indonesia. Then, we will, here, propose such a study/survey, i.e. who should investigate what, where, whom, when and how.

First, where, whom and what should we survey? In order to obtain representative prevalence figures, we need, first, to select areas (villages or towns) possibly throughout Indonesia as representative samples by reliable sampling method. We had better start such a prevalence study as a pilot study of investigating the feasibility of the survey and, therefore, we may select several areas at least at an initial stage where the survey would be considered to be successfully conducted and increase the number of areas to be studied afterward in order to satisfy the condition of "representativeness of the sampled population".

When selecting candidate areas (villages/towns), several sampling methods are available, as shown in Table 3 and for this purpose a probability proportionate sampling may be adequate and suitable. After selecting areas to be studied, we may adopt simple random sampling method to select inhabitants to be studied. Inhabitants to be selected at this stage should be those in childhood and in adolescence and those aged old enough to get skin cancer as well. For those in childhood and adolescence, information on present sun protection behaviors/practices will be collected and for those aged old enough to get skin cancer, past (in childhood and adolescence) and present (middle age and thereafter) information should be done. The items to be possibly collected in relation to sun protection behaviors/practices are listed in Table 4 and other information which should be inquired in Table 5 .

Table 3. Sampling method for candidate villages or towns and inhabitants to be studied

(1) Simple random sampling

(2) Systematic random sampling

(3) Probability proportionate sampling

(4) Stratified sampling

(5) Cluster sampling

(6) Multi-stage sampling

(7) Multi-phase sampling

(8) Sampling for time series

Table 4. Information to be collected by direct interview on sun protection behavior/practices

(1) Skin sensitivity (Skin type)

(2) Skin reaction after 1-hr sun exposure

(3) Skin reaction after long exposure to sun

(4) Use of protective clothing such as wide-brimmed hats / long-sleeved shirts

(5) Practices of Stay in shade

(6) Use of sunscreen / sunblock lotion

(7) Exposure to artificial source of ultraviolet light

(8) Other behaviors / practices (regular skin self-exam., etc)

Table 5. Basic information to be collected by direct interview

(1) Demographic information

Ethnic group, Age, Sex, Marital status, Education, Religion, Annual income, etc.

(2) Past and family history of skin cancer and other cancers

(3) Lifestyles

Cigarette smoking habits, Drinking habits, etc 
Second, who should collect all necessary information when and how? In order to undertake such a countrywide study, we need to organize certain study teams by whom an actual survey will be done at each area by directly interviewing individuals who are selected as study subjects (population samples) and such study teams should be, at a central administrative office, co-ordinated and integrated. Responsible interviewers should be sufficiently trained to maintain intra- and inter-viewer variations as minimal as possible, by using a standardized structured-questionnaire. Sun protection behaviors/practices will be different by season from area to area in Indonesia, but a survey at the hottest season at each area will be good enough for collecting all information.

Information to be disclosed by analyzing the data obtained from the proposed prevalence study in Indonesia

The major aim of the proposed prevalence study is to obtained the frequencies in percentage of those practicing each sin protection behavior/practice, which will be used for calculating PARP and ARN, and to know, as a final goal, the extend of primarily preventable proportion of NMSC in Indonesia. Other useful information to be disclosed are exemplified in Table 6. Ethnic group-specific analysis will also be useful in such a country with multi-ethnicity as Indonesia. Lifestyle and demographic characteristics should also be analyzed in relation to skin sensitivity and more importantly, to the likeliness of practicing sin protection in each life stage (childhood, adolescence. Middle age and thereafter).

Table 6. Exemplified information to be disclosed by data analysis

(1) Area/ethnic group-specific prevalence rates of skin sensitivity

(2) Area / ethnic group-specific prevalence rates of sun protection behaviors/practices

(3) Factors associated with likeliness of practicing sun protection (protective clothing, stay in shade, sunscreen/sunblock lotion)

(4) Factors associated with skin sensitivity

What should be emphasized in this type of prevalence study is as follows. Those studied in each area should be not discarded and also not regarded as those with no longer values after obtaining the relevant information. They should be deliberately followed up for a certain period of time in order to examine whether they finally develop skin cancer or not. This follow-up study will be named as a "population-based cohort study on skin cancer." In this paper, we proposed a prevalence study on sum protection behaviors/practices, but this type of study design and conceptual framework will also be applicable to other sites of cancer or any other diseases, when planning a primary prevention program.

\section{Ten simple ways to help cut the risk of developing skin cancer}

In the United States, skin cancer is the most common cancer, with about 800,000 new cases diagnosed every year and accounts for more than 2,000 deaths per year. ${ }^{12}$ Skin cancers, in general, are easily treated and highly curable when diagnosed early, but can be life-threatening when allowed to progress. Many cases of skin cancer could be prevented by a simple behavioral change (avoidance of excessive exposure to the sun) and therefore, the following 10 ways are suggested as a message for public at large in the United States.12 These 10 simple tips are also considered, in part, as useful for Indonesians, before Indonesia-specific guidelines are to be shown by us.

1) When outside, always use a sunscreen with a sun protection factor (SPF) of at least 15 on exposed parts of your body. Less-protective sunscreens may allow you to burn if the sun is strong or your exposure is long. Higher SPF levels are even better.

2) Reapply sunscreen frequently (about 2 hours or sooner if going swimming or perspiring very heavily).

3) Select a sunscreen that blocks UVA (ultraviolet A) and UVB (ultraviolet B) light.

4) Wear protective clothing such as hats or shirts when outside for any period of time.

5) Stay in the shade as much as possible. Ultraviolet rays from the sun area reflected off surrounding surfaces (particularly light-colored surfaces (particularly light-colored surfaces like sand and snow) and can be potentially reach you even in the shade. Therefore, sunscreen should still be used.

6) Avoid midday sun exposure. Ultraviolet rays from the sun are strongest (and are most damaging) between $10 \mathrm{AM}$ and $3 \mathrm{PM}$. If at all possible, try to stay indoors during this time or day. 
7) Avoid exposure of artificial sources of ultraviolet light such as lamps and tanning booths.

8) Be careful about protecting your children from the sun. Children who suffer severe sunburns during childhood are more likely to develop skin cancer later in life than children who never suffer sunburns. Sunscreen, however, is not recommended until 6 months of age (keep infants out of the sun as much as possible), but can be safely used after 6 months on most children.

9) Perform regular self-examinations of your skin (every month is recommended by the American Cancer Society).

10) Have your physician perform regular skin examinations (every year is recommended by the American Cancer Society).

\section{Acknowledgement}

We are indebted to the International Cancer Research Grant system, Monbusho, Japan and the Dean, Faculty of Medicine, University of Indonesia, Jakarta, for his approval of the Japan-Indonesia collaborative study. This work has been supported by the grant no. 09042004, under Ministry of Education, Science, Sport and Culture, Government of Japan and was partly supported by the Indonesian Cancer Foundation, the Jakarta International Cancer Conference Fund and the Terry Fox Foundation, Canada. The collaborative study was initiated with Dean's approval no. 845/PT02.H4.FK/E/97 and technical support by the
Director of Dr. Cipto Mangunkusumo National Central General Hospital.

\section{REFERENCES}

1. Marks R. An overview of skin cancers. Incidence and causation. Cancer 1995; 75: 607-12.

2. Corona R. Epidemiology of non-melanoma skin cancer: a review. Annal dell Instituo Superiore di Sanita, 1996; 32: $37-42$.

3. Quinn AG. Ultraviolet radiation and skin carcinogenesis. Brit J Hop Med 1997; 58: 261-4.

4. Ichihashi $M$, Naruse $K$, Harada $S$, et al. Trends in nonmelanoma skin cancer in Japan. Recent Results in Cancer Res 1995; 139: 264-73.

5. Kricker A, Armstrong BK, English DR. Sun exposure and non-melanocytic skin cancer. Cancer Causes and Control 1994; 5: 369-92.

6. Strom SS, Yamamura Y. Epidemiology of non-melanoma skin cancer. Clinics in Plastic Surgery, 1997; 24: 627-36.

7. English DR, Armstrong BK, Kricker A, Fleming C. Sunlight and cancer. Cancer Causes and Controls, 1997; 8: 271-83

8. American Cancer Society. Cancer facts and figures. Atlanta (GA): American Cancer Society, 1998.

9. Banks BA, Silverman RA. Schwartz RH, Tunnessen WW. Altitude of teenagers toward sun exposure and sun screen use. Pediatrics 1992; 89: 40-2.

10. Stern RS, Weinstein MC, Baker SG. Risk reduction for non-melanoma skin cancer with childhood sunscreen use. Arch Dermatol 1986; 122: 537-45.

11. Tominaga $S$, Ohno Y. Introduction to Epidemiology for Clinicians. Nihon-Izi-Shinpo-sya. Tokyo, 1989: 37-41 (in Japanese).

12. Page for patients, A message from Preventive Medicine and your physician. Preventive Medicine 1997; 26: 409. 